Article

\title{
Reuse of Lipase from Pseudomonas fluorescens via Its Step-by-Step Coimmobilization on Glyoxyl-Octyl Agarose Beads with Least Stable Lipases
}

\author{
Nathalia S. Rios ${ }^{1,2,+}$, Sara Arana-Peña ${ }^{1,+}{ }^{\text {, }}$ Carmen Mendez-Sanchez ${ }^{1}$, Claudia Ortiz ${ }^{3}$, \\ Luciana R. B. Gonçalves ${ }^{2}$ (D) and Roberto Fernandez-Lafuente ${ }^{1, *(\mathbb{D}}$ \\ 1 Departamento de Biocatálisis, ICP-CSIC, Campus UAM-CSIC, 289049 Madrid, Spain; \\ nathaliarios25@yahoo.com.br (N.S.R.); s.arana@csic.es (S.A.-P.); cmende02@ucm.es (C.M.-S.) \\ 2 Departamento de Engenharia Química, Universidade Federal do Ceará, Campus do Pici, Bloco 709, \\ Fortaleza CEP 60455-760, Brazil; lrg@ufc.br \\ 3 Escuela de Microbiología, Universidad Industrial de Santander, Bucaramanga 680002, Colombia; \\ ortizc@uis.edu.co \\ * Correspondence: rfl@icp.csic.es; Tel.: +34-915-854-941 \\ + Both authors have evenly contributed to this paper.
}

Received: 17 April 2019; Accepted: 22 May 2019; Published: 27 May 2019

\begin{abstract}
Coimmobilization of lipases may be interesting in many uses, but this means that the stability of the least stable enzyme determines the stability of the full combilipase. Here, we propose a strategy that permits the reuse the most stable enzyme. Lecitase Ultra (LU) (a phospholipase) and the lipases from Rhizomucor miehei (RML) and from Pseudomonas fluorescens (PFL) were immobilized on octyl agarose, and their stabilities were studied under a broad range of conditions. Immobilized PFL was found to be the most stable enzyme under all condition ranges studied. Furthermore, in many cases it maintained full activity, while the other enzymes lost more than $50 \%$ of their initial activity. To coimmobilize these enzymes without discarding fully active PFL when LU or RML had been inactivated, PFL was covalently immobilized on glyoxyl-agarose beads. After biocatalysts reduction, the other enzyme was coimmobilized just by interfacial activation. After checking that glyoxyl-octyl-PFL was stable in 4\% Triton X-100, the biocatalysts of PFL coimmobilized with LU or RML were submitted to inactivation under different conditions. Then, the inactivated least stable coimmobilized enzyme was desorbed (using $4 \%$ detergent) and a new enzyme reloading (using in some instances RML and in some others employing LU) was performed. The initial activity of immobilized PFL was maintained intact for several of these cycles. This shows the great potential of this lipase coimmobilization strategy.
\end{abstract}

Keywords: enzyme coimmobilization; glyoxyl-octyl; covalent immobilization; interfacial activation; reuse of coimmobilized enzymes

\section{Introduction}

Lipases are among the most utilized enzymes due to their high stability and activity in a wide range of reaction media. Their broad specificity, coupled to high enantio and regio selectivity and specificity, lack of cofactor requirements, and availability from very different sources, permits their use in many different reactions (even promiscuous ones) [1-4]. Lipases may be used in many different areas, from food technology to energy, from pharmaceutical chemistry to flavor synthesis, etc. [5-14].

In some instances, the key feature is the selectivity or the specificity of the biocatalyst. In these cases, a fully purified enzyme is preferred in order to avoid interferences between enzymes with different properties that can reduce the final purity of the product (e.g., resolution of racemic mixtures) [15]. 
However, these features become a problem when the biocatalyst is going to be utilized in the full modification of a heterogeneous substrate. This is the case of oils, either when they are hydrolyzed to produce free fatty acids or when they are used in transesterifications to produce biodiesel [16-23]. It should be considered that the oil will be composed of many different triglycerides formed by different fatty acids. Moreover, diglycerides and monoglycerides will be the main substrates in certain moments of the modification. Even in hydrolysis reactions, where titration of the released acids is not recommended to avoid soap formation, the $\mathrm{pH}$ will decrease throughout the reaction [23]. That way, neither the nature of the substrate is constant and unique, nor will the experimental conditions be fixed. Thus, it is not easy to find an "optimal" enzyme that may be the best one in all situations. In these cases, it has been shown that the combined use of several lipases permits not only better yields but also higher initial reaction rates and more lineal reaction courses (in some cases one enzyme eliminates an inhibitor of the main enzyme) [16-23]. Usually, this has been obtained using mixtures of individually immobilized lipases [16-23].

If a combilipases is going to be utilized, lipase coimmobilization must be considered. Coimmobilization of different lipases may have advantages in these reactions, as this avoids any time lag in the sequential full modification of oils because lipases are immobilized on the same particle and intermediate products do not need to diffuse to other enzyme particle [24-26].

However, enzyme immobilization is not a trivial matter in biocatalysts design. Any immobilization protocol should make a heterogeneous biocatalyst easy to separate from the reaction medium [27]. Furthermore, a proper enzyme immobilization protocol may improve many enzyme properties, like enzyme stability, activity, selectivity or specificity, purity, or inhibition problems [28-33]. Thus, coimmobilization of several enzymes may be disadvantageous, as the same immobilization protocol may not be the optimal one for all involved enzymes. This way, some of the immobilization potential to improve enzyme properties may be lost for some of the involved enzymes [34-36]. However, this may be not so hard a problem to solve when coimmobilizing lipases. In lipase immobilization, there is a protocol that has revealed itself as an almost ideal method for the immobilization of most lipases [37]: the use of hydrophobic supports permits lipase immobilization via interfacial activation of the lipase versus the support surface [38], enabling the one step immobilization, purification, stabilization, and even hyperactivation (the open form of the lipase is stabilized) of the lipase [39,40]. Enzyme thermal stabilization using this protocol is higher even than that achieved using multipoint covalent immobilization in thermal inactivations [41-44].

However, a second problem of enzyme coimmobilization remains: after the inactivation of the least stable enzyme, all immobilized enzymes must be discarded [34-36]. Using hydrophobic supports, lipase desorption may be achieved using detergents and the support may be reused, but more often than not all lipases will be released from the support, and we may discard one enzyme with full activity [37]. This may be solved if we used a heterofunctional glyoxyl-acyl support and the most stable enzyme is covalently bound to the support after a first immobilization via interfacial activation $[45,46]$. These heterofunctional supports have been used with diverse lipases, showing that they permit the first immobilization via interfacial activation (glyoxyl groups are not able to immobilize monomeric enzymes at $\mathrm{pH}$ 7) [47] and, later, the covalent attachment of the already immobilized enzymes by alkaline incubation on the glyoxyl groups may be achieved. This fully avoids the release of the enzyme and, in most cases, permits enzyme stabilization, mainly in the presence of organic cosolvents $[37,45,46]$. After reduction of the support, the enzyme/enzymes with a lower stability is/are immobilized on the biocatalyst via interfacial activation (the support chemical reactivity is gone). That way, these unstable and inactivated enzymes may be released from the biocatalyst using detergents, while the other stable and active enzymes will remain attached to the support and may be reused.

This coimmobilization strategy has been reported using the lipase B from Candida antarctica (CALB) (a very stable enzyme) [48] and Lecitase Ultra (LU) (a phospholipase) [49] and the lipase from Rhizomucor miehei (RML) [50-52]. As explained above, one requirement of the strategy is that the enzyme covalently attached to the support must be the most stable one under the operational 
conditions. In the previous paper, a fixed inactivation condition (one thermal inactivation at a $\mathrm{pH}$ 7) was used to evaluate the enzymes stabilities, and combilipases were always formed by the same pair of coupled enzymes (CALB-LU or CALB-RML).

In this new research, we analyze the possibility of co-immobilizing the lipases from Pseudomonas fluorescens (PFL), and RML and the phospholipase LU. These enzymes are very interesting ones, utilized in many biocatalytic reactions $[50,51,53,54]$. All of them have been immobilized on octyl agarose and glyoxyl-octyl agarose with good results $[45,55]$.

Now, we will try to exploit the strategy to prepare coimmobilized combilipases to show that it may be compatible with different inactivation causes (provided that the least stable enzymes remain much less unstable than the other enzyme under all conditions), and that the covalently attached enzyme may be coimmobilized each time with a different less stable enzyme. That is, the versatility of the protocol will be enlarged and the applications ranged will grow.

To this end, first the stability of the different lipases to be coimmobilized will be compared under different conditions. Then, the most stable lipase will be immobilized on glyoxyl-octyl. After alkaline incubation to get some covalent bonds, the biocatalyst will be reduced to eliminate the chemical reactivity of the support. Then, one of the least stable enzymes will be coimmobilized with the covalently immobilized enzyme but only via interfacial activation. After checking the effect of detergents on the stability of the most stable and covalently attached enzyme, the biocatalyst will be incubated under conditions where the least stable enzyme is inactivated but the most stable is left untouched. After this inactivation incubation, the inactivated enzyme will be released by detergent incubation. This will allow one to reuse the most stable enzyme, and to coimmobilize via interfacial activation other different, less stable enzymes. The combi-biocatalyst may be submitted to several inactivation cycles under different conditions. This reuse of the most stable enzyme (covalently attached) and changes of both inactivation conditions and the coimmobilized pair of enzymes will be repeated for several cycles.

\section{Results and Discussion}

\subsection{Immobilization on Octyl-Agarose and Comparison of Stabilities of RML, LU, and PFL}

Figure 1 shows the immobilization courses of RML, LU, and PFL on octyl agarose. LU and RML increased the activity by a factor of 5, while in the case of PFL this increase in enzyme activity after immobilization is scarce (around 10\%). This increase in lipase activity upon immobilization on octyl-agarose has been previously described and is related to the stabilization of the open form of the lipases [37].

To decide the enzyme or enzymes that should be covalently immobilized on glyoxyl-octyl agarose and the range of conditions where the combilipases permit the reuse of the most stable one with full activity, it was necessary to compare the stability of the three biocatalysts under all desired conditions. This will also show the best couple of enzymes for each inactivation condition (it is convenient to find conditions where one remains almost $100 \%$ active while the other enzyme has lost more than $50 \%$ of the initial activity).

Lipase stabilities were higher at $\mathrm{pH} 5$ than at $\mathrm{pH} 7$ (except for RML), and all enzymes showed their lowest stabilities at $\mathrm{pH}$ 9. Thus, at $\mathrm{pH} 7$ and 5 the enzymes were inactivated at $55^{\circ} \mathrm{C}$ and at $\mathrm{pH} 9$ they were inactivated at $42^{\circ} \mathrm{C}$. Figure 2 shows the inactivation courses of octyl-LU, octyl-RML, and octyl-PFL at $\mathrm{pH} 5,7$, and 9 under the selected temperatures. PFL was the most stable one under all conditions, maintaining $100 \%$ of the initial activity at $\mathrm{pH} 7$ and 9 under conditions where the other 2 enzymes retained less than $50 \%$ of the initial activity. LU was the biocatalyst with the lowest stability at $\mathrm{pH} 5$ and 7, while RML was the one with a lower stability at $\mathrm{pH}$ 9. At $\mathrm{pH}$ 5, a lower temperature was assayed $\left(50^{\circ} \mathrm{C}\right)$, as even PFL suffered a slight inactivation at $55^{\circ} \mathrm{C}$. Under these conditions, PFL maintained its activity intact while RML showed more than $80 \%$ activity after $2 \mathrm{~h}$ of inactivation but LU lost a significant percentage of enzyme activity. 
A

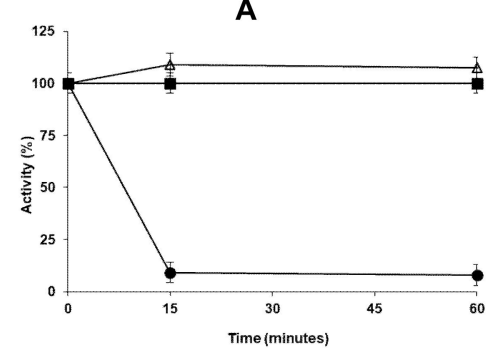

B

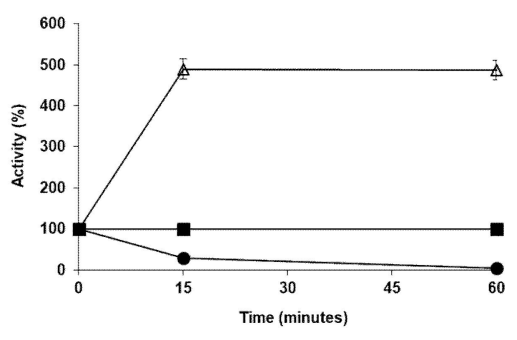

C

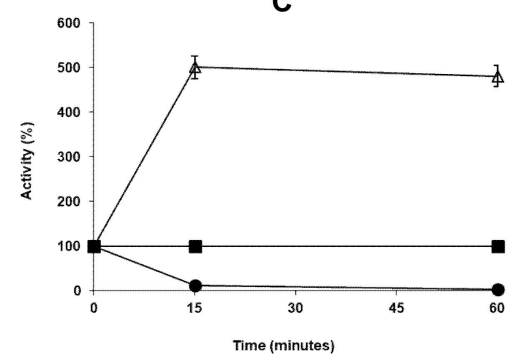

Figure 1. Immobilization course Pseudomonas fluorescens (PFL) (A), Rhizomucor miehei (RML) (B), and Lecitase Ultra (LU) (C) in octyl agarose beads. The experiments were performed using an enzyme loading of $1 \mathrm{mg} / \mathrm{g}$ of support as described in Methods. Solid squares: reference, solid circles: supernatant; and empty triangles: suspension.

A

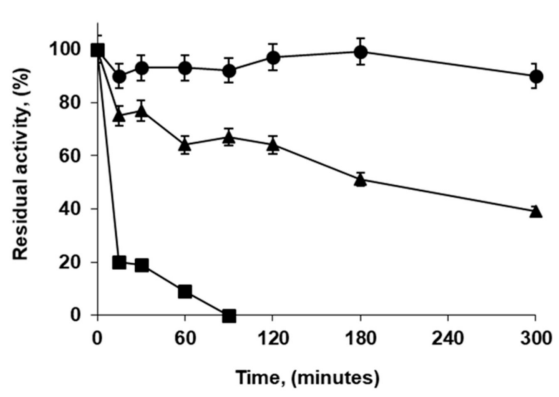

C

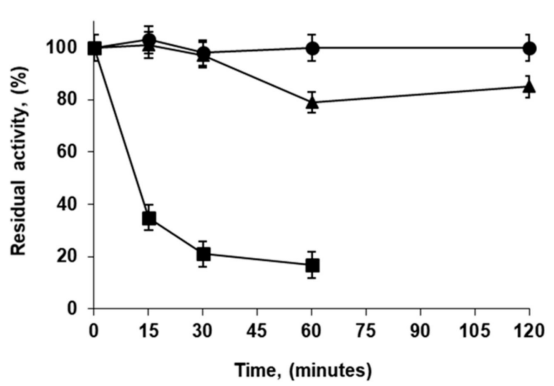

B

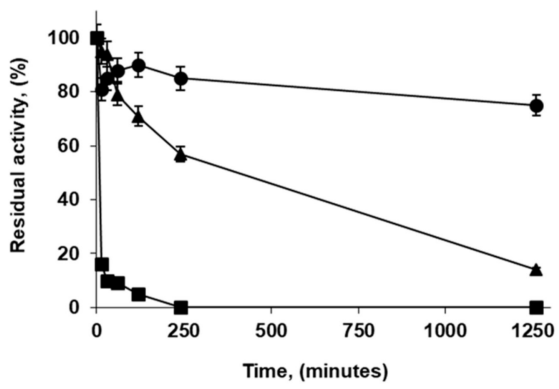

D

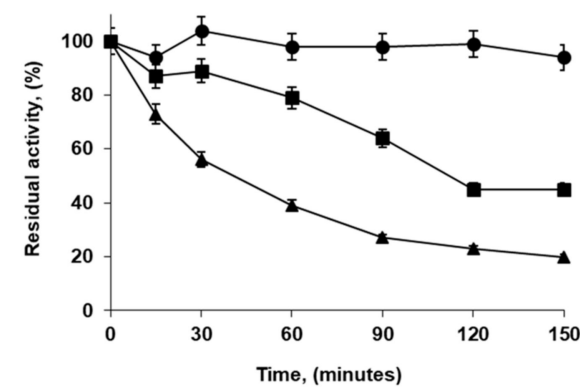

Figure 2. Inactivation profiles of different lipase biocatalysts incubated under different conditions. Other specifications are described in methods. $55^{\circ} \mathrm{C}, \mathrm{pH} 7$ (A); $55^{\circ} \mathrm{C}, \mathrm{pH} 5$ (B); $50{ }^{\circ} \mathrm{C}, \mathrm{pH} 5$ (C); and $42{ }^{\circ} \mathrm{C}$, pH 9 (D). Solid circles: octyl-PFL; solid triangles: octyl-RML; and solid squares: octyl-LU.

Following our objective, these inactivation results suggested that PFL should be the enzyme to be covalently attached to the support, and RML or LU could be coimmobilized with it just via interfacial activation, enabling one to maintain the immobilized PFL as almost fully active when the other enzymes were almost fully inactive. At pH 5, RML stability was too high to be coimmobilized 
with PFL and recover intact the activity of PFL after a 50\% inactivation of RML; thus, the couple $\mathrm{PFL} / \mathrm{RML}$ was not adequate at this $\mathrm{pH}$ value. However, at $\mathrm{pH} 7$ and 9 both LU and RML were clearly less stable than PFL. Thus, except at pH 5, PFL covalently immobilized on glyoxyl-octyl could be coimmobilized with any of the other enzymes and the full PFL activity recovered after the inactivation of the coimmobilized enzyme. At $\mathrm{pH} 5,50^{\circ} \mathrm{C}$ was required to inactivate $\mathrm{LU}$ while keeping full activity for PFL.

However, in many instances the combilipases may be used in the presence of organic solvents. Thus, the stabilities of the three biocatalysts in the presence of $30 \%$ of different organic solvents at $25^{\circ} \mathrm{C}$ were assayed (Figure 3). Again, PFL was always the most stable biocatalyst but only LU was clearly inactivated using this moderately low concentration of acetonitrile, dimethylformamide, or dioxane (Figure 3). To get a significant inactivation of immobilized RML, using dioxane and acetonitrile, the temperature was increased to $30{ }^{\circ} \mathrm{C}$ or the solvent concentrations were increased by $40 \%$, to obtain conditions that permitted one to inactivate all immobilized enzymes except the PFL preparation. Figure 4 confirms that PFL retained its activity almost unaltered under all these conditions, except when combining $30 \%$ dioxane and $30{ }^{\circ} \mathrm{C}$, while LU and RML lost more than $50 \%$ of their activities. That means that using RML and LU coimmobilized with covalently immobilized PFL on glyoxyl-octyl could be possible to reuse a fully active PFL when the other enzymes were significantly inactivated.

A
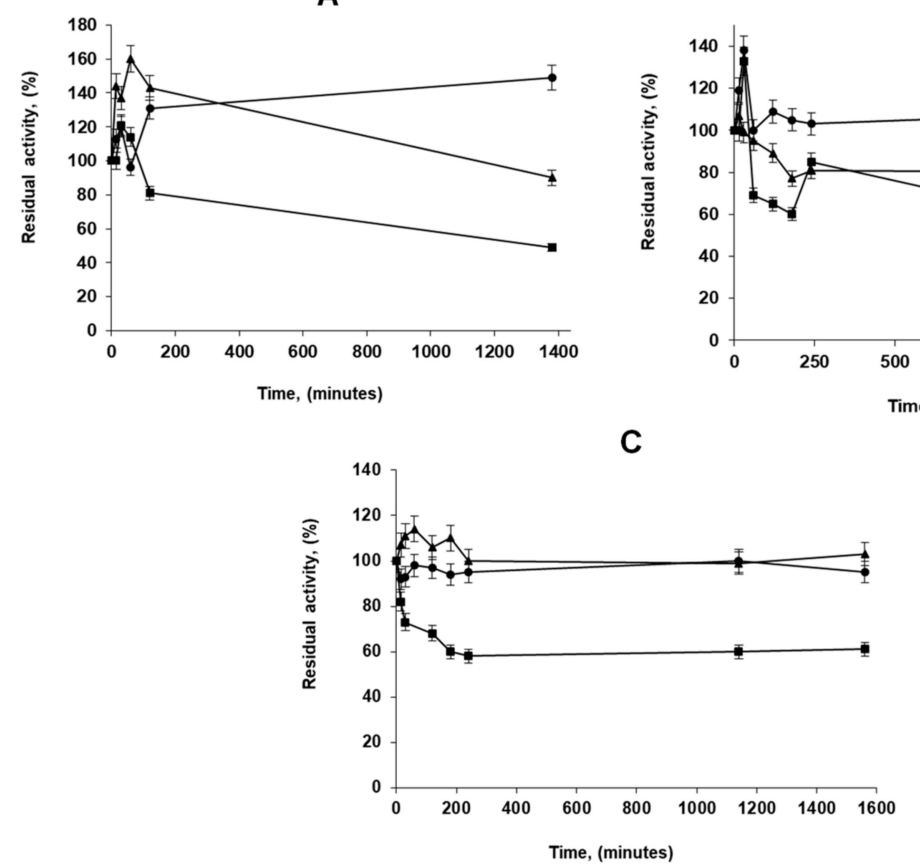

B
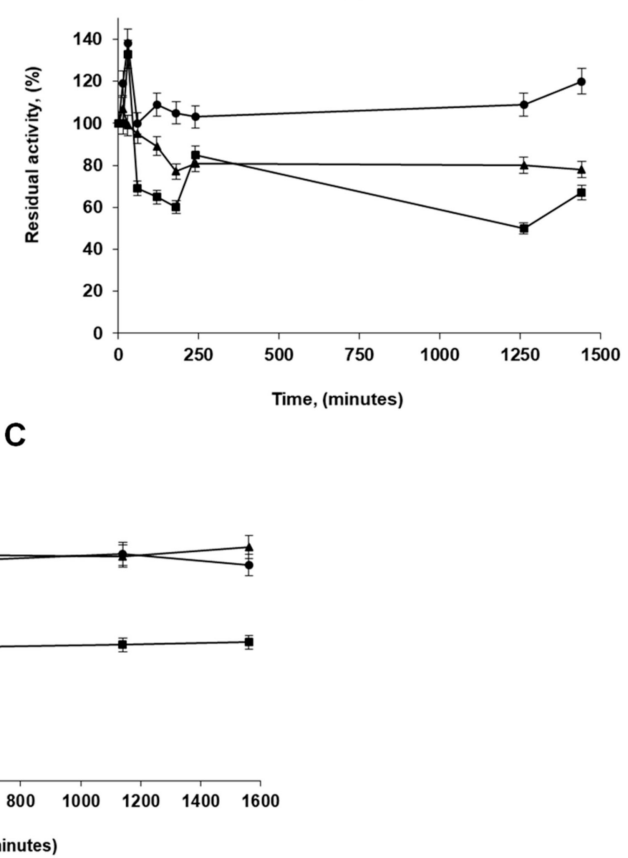

Figure 3. Inactivation profile of different lipase preparations incubated in the presence of $30 \%(v / v)$ of different cosolvents. Acetonitrile (A); 1,4-dioxane (B); and dimethylformamide (C). The experiments were performed at $\mathrm{pH} 7$ and $25^{\circ} \mathrm{C}$ as described in Methods. Solid circles: octyl-PFL; solid triangles: octyl-RML; and solid squares: octyl-LU.

Thus, it seems that the best option to prepare a combilipase for its use under any experimental condition, with the possibility of reusing the most stable enzyme, was to covalently immobilize PFL on glyoxyl-octyl agarose and coimmobilize the other two enzymes in the reduced biocatalyst. 
A
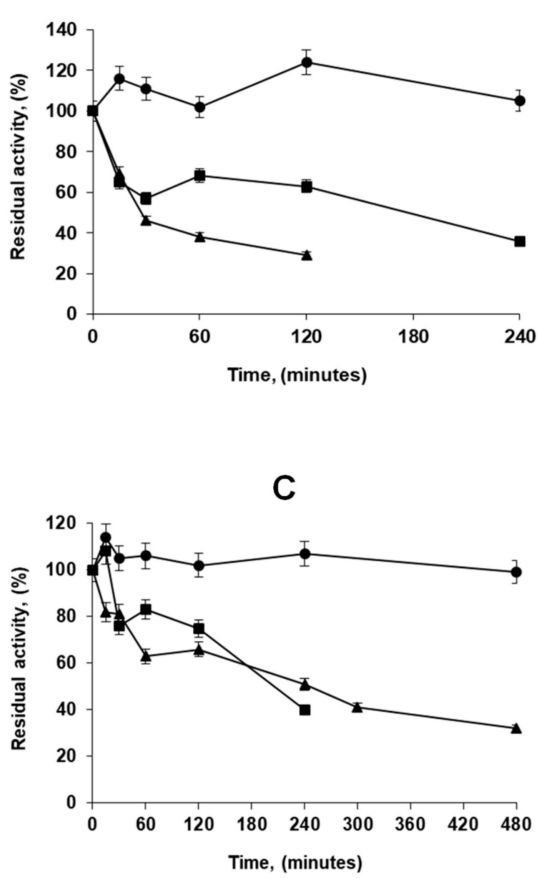

B

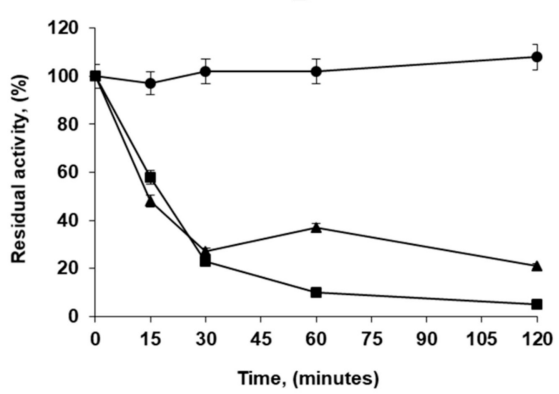

D

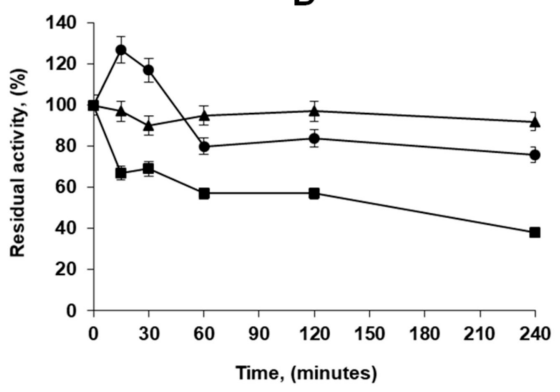

Figure 4. Inactivation profiles of different lipase preparations incubated under different conditions.: in the presence of $40 \%(v / v)$ acetonitrile at $25{ }^{\circ} \mathrm{C}(\mathbf{A})$; in $30 \%(v / v)$ acetonitrile at $30{ }^{\circ} \mathrm{C}(\mathbf{B})$; in $40 \%$ $(v / v)$ 1,4-dioxane at $25{ }^{\circ} \mathrm{C}(\mathrm{C})$; and $30 \%(v / v)$ 1,4-dioxane at $30{ }^{\circ} \mathrm{C}(\mathrm{D})$. The experiments were carried out at pH 7. Other specifications are described in Methods. Solid circles: octyl-PFL; solid triangles: octyl-RML; and solid squares: octyl-LU.

\subsection{Effect of Detergent on PFL-Glyoxyl-Octyl Stability}

It has been described that the desorption of the inactivated enzymes immobilized via interfacial activation may be achieved after their incubation in $4 \%$ Triton for $1 \mathrm{~h}$ [52]. This will be not possible if the covalently immobilized enzyme is inactivated by the detergent. Thus, we checked if this detergent had any negative effect on the activity of the covalently immobilized PFL, and we did not find any significant enzyme activity decrease even after more than 1 day of incubation in $4 \%$ Triton X-100 (Figure 5). That meant that it was possible to coimmobilize PFL immobilized on reduced glyoxyl-octyl agarose and LU or RML, and release LU and RML from the biocatalyst by incubation in 4\% Triton-X100 without any negative effect for the covalently immobilized PFL.

One of the problems that may exist with this strategy is the presence of some leftover Triton X-100 molecules on the support or the enzyme even after washing the biocatalysts to eliminate the inactivated enzymes and the residual detergent. This could have some negative effect on enzyme stability [52]. Thus, the stability of the immobilized PFL after incubation in 4\% Triton X-100 and the corresponding washing was compared with that of a biocatalyst not incubated in detergent, and we did not find any difference in terms of enzyme stability (Figure 6). Similar studies were performed comparing the stabilities of LU and RML immobilized on supports that have been incubated in detergent solution or clean supports, with similar results (Figure 6). This means that all Triton X-100 molecules were eliminated from the supports and biocatalyst or that they have no effect on the enzymes stabilities. 


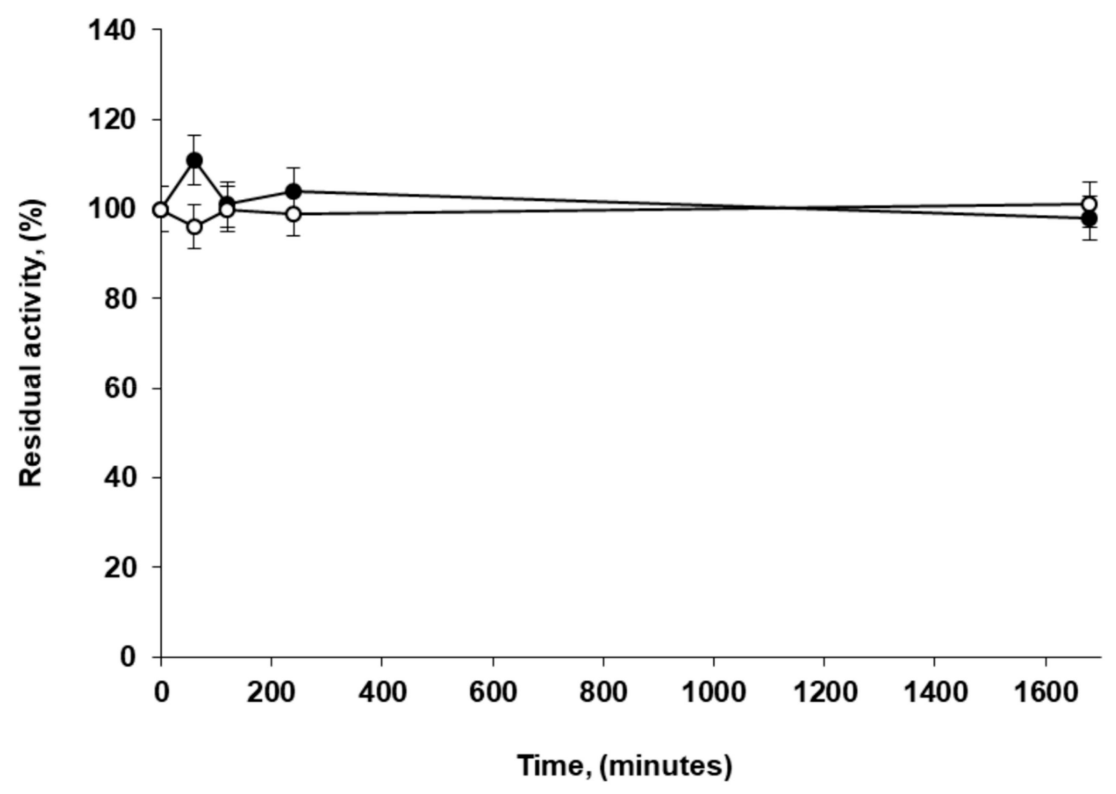

Figure 5. Effect of the incubation in 4\% Triton X-100 on the activity of glyoxyl-octyl-PFL biocatalyst. The lipase preparation was incubated in $4 \%(v / v)$ of Triton X-100 at $\mathrm{pH} 7$ and $25^{\circ} \mathrm{C}$. Experiments were performed as described in Methods. Empty circles: glyoxyl-octyl-PFL (control); solid circles: glyoxyl-octyl-PFL in presence of Triton X-100.
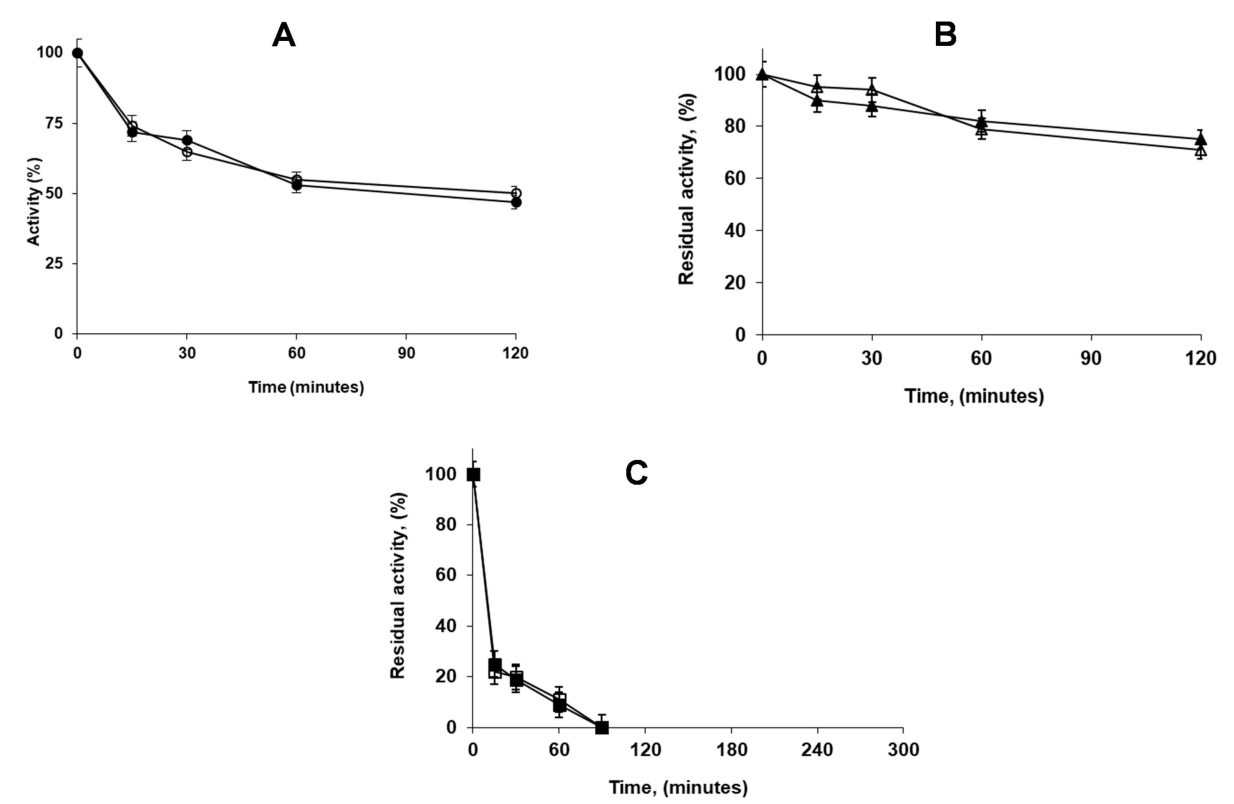

Figure 6. Effect of incubation in the presence of $4 \%$ Triton X-100 of the supports and washing as described in methods on the stability of glyoxyl-octyl-PFL at $70{ }^{\circ} \mathrm{C}, \mathrm{pH} 7$ (A). Reduced glyoxyl-octyl was submitted to the same protocols, and then RML (B) or LU (C) were immobilized. Inactivation was performed at $55{ }^{\circ} \mathrm{C}$ and $\mathrm{pH}$ 7. Experiments were performed as described in Methods. Empty symbols: enzyme immobilized in supports without incubation with Triton X-100 (control); solid symbols: enzyme immobilized on support incubated in Triton X-100 and washed with distilled water as described in methods.

\subsection{Preparation of Combi PFL-RML and Combi PFL-LU}

Figure 7 shows the coimmobilization of RML and LU with reduced glyoxyl-octyl PFL. The immobilization is quite rapid and produces some hyperactivation of the enzymes, but lower than 
when immobilizing the enzymes individually, very likely because PFL will be immobilized on the external section of the support pores. However, hyperactivation still showed a factor of 2 for LU and of almost 3 for RML. Figure 8 shows the SDS-Page: it shows how the bands of LU or RML are visible and how after Triton X100 incubation no bands were detected.

A

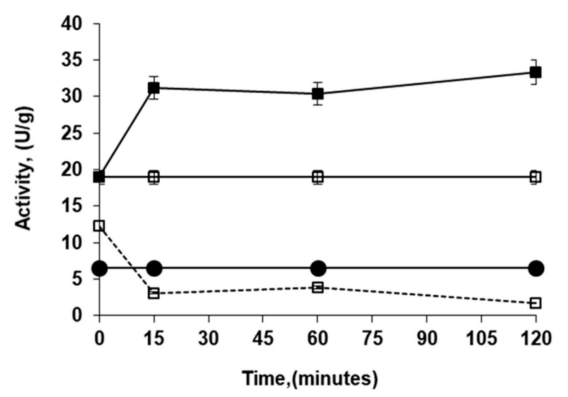

B

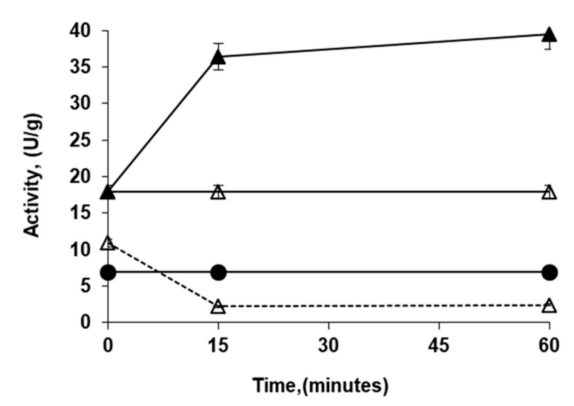

Figure 7. Courses of immobilization in the production of combibiocatalysts. Activity is given per gram of wet support used in the experiment. Experiments were carried out as described in Methods: (A) LU immobilized on reduced glyoxyl-octyl-PFL. Solid line, empty square: LU reference; solid line, solid square: suspension; dotted line, empty squares: supernatant; solid line, solid circle: reduced glyoxyl-octyl-PFL reference. (B) RML immobilized on reduced glyoxyl-octyl-PFL. Solid line, empty triangle: RML reference; solid line, solid triangle: suspension; dotted line, empty triangle: supernatant; solid line, solid circle: reduced glyoxyl-octyl-PFL.

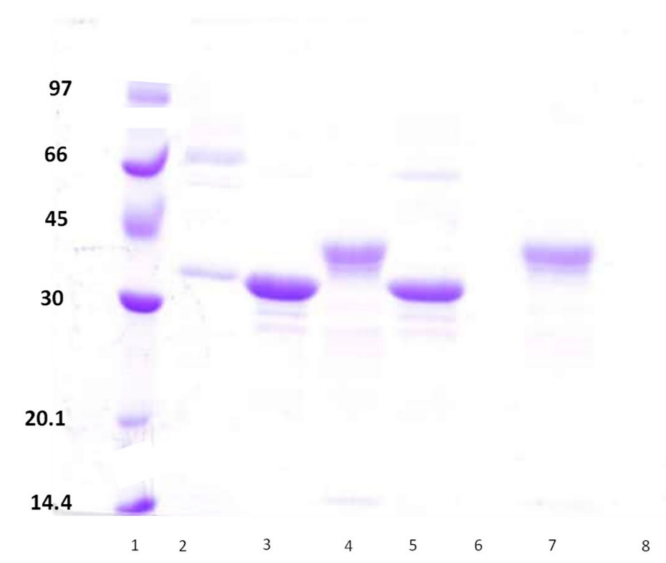

Figure 8. SDS-page analysis of combi-biocatalysts PFL-RML/PFL-LU. Lane 1: molecular weight marker, Lane 2: octyl-PFL; Lane 3: octyl-RML; Lane 4: octyl-LU; Lane 5: COMBI-PFL-RML; Lane 6: COMBI-PFL-RML washed with triton 4\%; Lane 7: COMBI-PFL-LU; and Lane 9: COMBI-PFL-LU washed with triton $4 \%$. Experiments were performed as described in Methods.

\subsection{Cycles of Enzyme Inactivation, Inactivated Enzyme Desorption, and New Enzyme Loading}

Figure 9 shows several cycles of incubation under stress conditions of PFL-glyoxyl-octyl preparation, coimmobilized in some cases with RML and in other cases with LU. The inbutation was prolonged until the least stable enzyme was inactivated under $50 \%$ of its initial activity, then it was desorbed from the biocatalysts, and a load of other fresh enzyme was added to the immobilized PFL to get a new combilipase. Inactivations involve different $\mathrm{pHs}$, temperatures, and organic solvents, were we have previously verified that PFL remains fully active. 


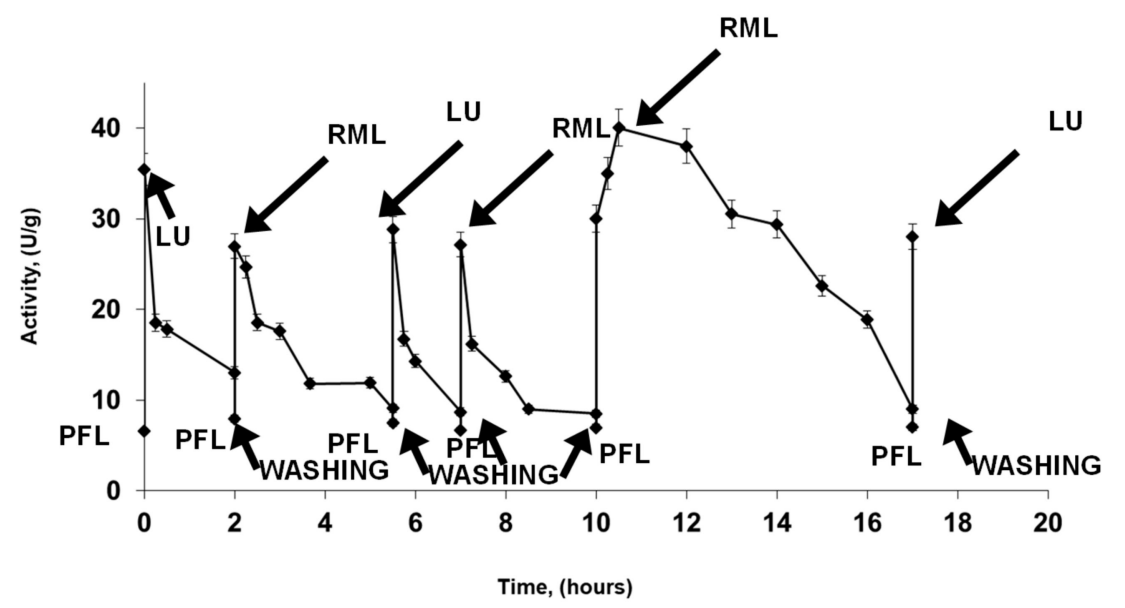

Figure 9. Cycles of reuse of reduced glyoxyl-octyl-PFL in the preparation of combilipases after immobilization of LU or RML and its inactivation and desorption and washing as described in Methods section. PFL is PFL covalently immobilized on glyoxyl-octyl. First cycle: LU was immobilized on reduced glyoxyl-octyl-PFL and inactivated at $50{ }^{\circ} \mathrm{C}, \mathrm{pH}$ 5; second cycle: fresh RML was immobilized on reduced glyoxyl-octyl-PFL and inactivated at $42{ }^{\circ} \mathrm{C}, \mathrm{pH}$ 9; third cycle: fresh LU was immobilized on reduced glyoxyl-octyl-PFL and inactivated in presence of $30 \%$ acetonitrile at $30{ }^{\circ} \mathrm{C}, \mathrm{pH} 7$; fourth cycle: fresh RML was immobilized on reduced glyoxyl-octyl-PFL and inactivated in presence of $40 \%$ acetonitrile at $25^{\circ} \mathrm{C}, \mathrm{pH} 7$; and fifth cycle: fresh RML was immobilized on reduced glyoxyl-octyl-PFL and inactivated at $55{ }^{\circ} \mathrm{C}, \mathrm{pH}$ 7. After all inactivations cycles, the lipase preparations were incubated in $4 \%(v / v)$ of Triton X-100 during $1 \mathrm{~h}$ to desorb all lipases hydrophobic adsorbed on the support.

It is clear that PFL activity after desorption of the inactivated LU or RML was maintained for 5 different inactivation, desorption, and new enzyme coimmobilization cycles, where the combi-biocatalysts are incubated at different $\mathrm{pH}$ values and in the presence of different organic solvents. That is, the strategy works under a broad range of conditions and permits the coimmobilization of different enzymes.

\section{Materials and Methods}

\subsection{Materials}

Lipase from Pseudomonas fluorescens (PFL-13.2\% mg of protein/mg of powder) was purchased from Sigma-Aldrich. Palatase 20,000 L (lipase from Rhizomucor miehei (RML)-2.9 mg of protein per mL) and Lecitase Ultra (LU), a chimeric phospholipase (21.85 mg of protein per $\mathrm{mL}$ ), were kindly donated by Novozymes (Spain). Triton X-100, $p$-Nitrophenyl butyrate ( $p$-NPB), sodium (meta) periodate, and sodium borohydride $\geq 98 \%$ were also purchased from Sigma-Aldrich. Octyl-Sepharose $\mathrm{Cl}-4 \mathrm{~B}$ beads were obtained from GE healthcare. All other reagents and solvents were of analytical grade.

\subsection{Methods}

\subsubsection{Immobilization of Lipases on Octyl-Agarose Beads}

Lipase from Pseudomonas fluorescens (PFL), lipase from Rhizomucor miehei (RML), and Lecitase Ultra (LU) were immobilized on octyl agarose by interfacial adsorption. To this goal, $1 \mathrm{~g}$ of support was added to $10 \mathrm{~mL}$ of lipase solution (containing $0.1 \mathrm{mg} / \mathrm{mL}$ ) in sodium phosphate $5 \mathrm{mM}$ at $\mathrm{pH} 7$. Finally, the biocatalysts were filtered, washed with excess of distilled water, and stored at $4{ }^{\circ} \mathrm{C}$.

\subsubsection{Coimmobilization of Lipases}

In this strategy, the most stable lipase was immobilized on glyoxyl-octyl agarose support, containing $20 \mu \mathrm{mol}$ of aldehydes per $\mathrm{g}$ of wet support. First, the most stable lipase was immobilized by 
interfacial activation, using $5 \mathrm{mM}$ sodium phosphate buffer at $\mathrm{pH} 7$ (1 $\mathrm{mg}$ of protein per $\mathrm{g}$ of support). In the procedure, $1 \mathrm{~g}$ of glyoxyl-octyl agarose was added to $10 \mathrm{~mL}$ of $0.1 \mathrm{mg} / \mathrm{mL}$ lipase solution and the immobilization process was carried out at room temperature. The immobilized lipase was filtered and washed with abundant distilled water. Then, the lipase immobilized on glyoxyl-octyl agarose was incubated at $\mathrm{pH} 10.5$ for $20 \mathrm{~h}$ at $25^{\circ} \mathrm{C}$ to get some covalent bonds [56]. Then, the support was reduced using $1 \mathrm{mg}$ of sodium borohydride per $\mathrm{mL}$ of suspension. The suspension was stirred for $30 \mathrm{~min}$ at $25^{\circ} \mathrm{C}$. Then, the covalent immobilized biocatalyst was filtered, washed with distilled water, and stored at $4{ }^{\circ} \mathrm{C}$.

In the sequential formation of combi-biocatalyst, the least stable lipase was immobilized on reduced covalently immobilized biocatalyst, using sodium phosphate buffer $5 \mathrm{mM}, \mathrm{pH} 7$. Then, the combi-biocatalyst was filtered, washed with distilled water, and stored at $4{ }^{\circ} \mathrm{C}$.

\subsubsection{Determination of Enzymatic Activity and Protein Concentration}

The enzymatic activity was measured using $p$-nitrophenyl butyrate ( $p$-NPB) substrate. $50 \mu \mathrm{L}$ of substrate ( $50 \mathrm{mM}$ in acetonitrile) was added to $2.5 \mathrm{~mL}$ of $25 \mathrm{mM}$ sodium phosphate at $\mathrm{pH} 7$, and the reaction was started by adding 50-100 $\mu \mathrm{L}$ of enzyme solution or suspension (free or immobilized). The product, $p$-nitrophenol, released during the hydrolysis of $p$-NPB, was measured at $348 \mathrm{~nm}$. Protein concentration was determined using Bradford method [57], and bovine serum albumin was used as standard.

\subsubsection{Immobilized Lipase Inactivations}

The stabilities of immobilized lipases were performed at different $\mathrm{pH}$ values $(50 \mathrm{mM}$ of sodium acetate at $\mathrm{pH} 5$, Tris- $\mathrm{CLH} / \mathrm{NaOH}$ at $\mathrm{pH} 7$, and sodium bicarbonate-carbonate at $\mathrm{pH} 9$,) using different temperatures $\left(42-55{ }^{\circ} \mathrm{C}\right)$ to find those that permitted a rapid and reliable least stable enzymes inactivations. In addition, the stability of immobilized preparations was investigated in the presence of $30-40 \%$ of different solvents in $50 \mathrm{mM}$ Tris- $\mathrm{HCl} / \mathrm{NaOH}$ at $\mathrm{pH} 7$ different temperatures. The stability of some preparations in presence of $4 \%(v / v)$ Triton X-100 (in $50 \mathrm{mM}$ Tris- $\mathrm{ClH} / \mathrm{NaOH}$ at $\mathrm{pH} 7$ ) at $25^{\circ} \mathrm{C}$ was also studied.

Periodically, samples were withdrawn, and their activities were determined employing the p-NPB hydrolysis. The profile of enzyme inactivation was built using as $100 \%$ the initial activity of the respective lipase preparation.

\subsubsection{Desorption of Lipases from the Support}

To eliminate the least stable enzyme from the support, the combi-lipase was incubated in $4 \%(v / v)$ of Triton X-100 in $50 \mathrm{mM}$ Tris- $\mathrm{ClH} / \mathrm{NaOH}$ at $\mathrm{pH} 7$ for $1 \mathrm{~h}$. Following that, the biocatalyst was washed five times with 10 volumes of Triton X-100 (4\%-v/v) and 50 times with 10 volumes of distilled water to remove all detergent molecules.

\subsubsection{SDS-Page Electrophoresis}

The SDS-Page analysis was performed using a Miniprotean tetra-cell (Biorad) electrophoresis unit. $12 \%$ polyacrylamide resolution gel and $5 \%$ polyacrylamide concentration gel were used for electrophoresis [58]. The samples were re-suspended in the rupture buffer (4\% $v / v$ SDS () and $10 \%(\mathrm{v} / \mathrm{v})$ mercaptoethanol ) for a final protein concentration of $1-2.5 \mathrm{mg} / \mathrm{mL}$. Then, the samples were boiled for $5 \mathrm{~min}$, enabling the release of all enzymes not covalently attached on the support [59], and $13 \mu \mathrm{L}$ of supernatant of the samples were loaded in the gel. Then, protein bands were detected by cromassie brilliant blue method, using low molecular weight marker protein (LMW-SDS Marker-GE Healthcare Life Sciences-14.4-97 KDa) as standard. 


\section{Conclusions}

Immobilized PFL was more stable than immobilized RML or LU under a wide range of conditions, maintaining its activity unaltered when the other biocatalysts were almost fully inactivated. The use of glyoxyl-octyl enabled one to covalently immobilize PFL after its immobilization via interfacial activation, and after reduction to eliminate the support chemical reactivity, to coimmobilize this enzyme with LU or RML. After incubation with Triton X-100, LU and RML was released from the support. As PFL-glyoxyl-octyl was not affected by incubation in $4 \%$ Triton X-100, it was possible to submit the coimmobilized enzymes (PFL/RML or PFL/LE) to incubation under stress conditions, where LU or RML were inactivated but PFL activity was almost fully maintained, release the inactivated enzyme, and load a new enzyme on the reduced PFL-glyoxyl-octyl. Thus, we have shown that the strategy is compatible with changes in the enzymes coimmobilized with the covalently and more stable immobilized enzyme, and with different causes for enzyme inactivation.

Author Contributions: N.S.R., S.A.-P., and C.M.-S.: Investigation, writing-original draft preparation and investigation, C.O., L.R.B.G.; writing-review and editing, funding acquisition, R.F.-L. supervision, funding acquisition, writing - original draft preparation and review and editing.

Funding: This research was funded by MICIU, grant number CTQ2017-86170-R and Colciencias grant number FP 44842-076-2016). N.S.R. thanks to CNPq for a predoctoral fellowship (CNPq scholarship-Brazil).

Acknowledgments: Martinez (Novozymes, Spain) is gratefully recognized for donatingthe enzymes. The help and suggestions from Ángel Berenguer (Departamento de Química Inorgánica, Universidad de Alicante) are gratefully recognized.

Conflicts of Interest: The authors declare no conflict of interest.

\section{References}

1. Jaeger, K.-E.; Eggert, T. Lipases for biotechnology. Curr. Opin. Biotechnol. 2002, 13, 390-397. [CrossRef]

2. Jaeger, K. Microbial lipases form versatile tools for biotechnology. Trends Biotechnol. 1998, 16, $396-403$. [CrossRef]

3. Schmid, R.D.; Verger, R. Lipases: Interfacial Enzymes with Attractive Applications. Analysis 1998, 37, 1608-1633. [CrossRef]

4. Reis, P.; Holmberg, K.; Watzke, H.; Leser, M.E.; Miller, R. Lipases at interfaces: A review. Adv. Colloid Interface Sci. 2009, 147-148, 237-250. [CrossRef]

5. Tan, T.; Lu, J.; Nie, K.; Deng, L.; Wang, F. Biodiesel production with immobilized lipase: A review. Biotechnol. Adv. 2010, 28, 628-634. [CrossRef] [PubMed]

6. Ghanem, A. Trends in lipase-catalyzed asymmetric access to enantiomerically pure/enriched compounds. Tetrahedron 2007, 63, 1721-1754. [CrossRef]

7. Aravindan, R.; Anbumathi, P.; Viruthagiri, T. Lipase application in food indrustry. Indian J. Biotechnol. 2007, 6, 141-158.

8. Stergiou, P.-Y.; Foukis, A.; Filippou, M.; Koukouritaki, M.; Parapouli, M.; Theodorou, L.G.; Hatziloukas, E.; Afendra, A.; Pandey, A.; Papamichael, E.M. Advances in lipase-catalyzed esterification reactions. Biotechnol. Adv. 2013, 31, 1846-1859. [CrossRef] [PubMed]

9. Sharma, S.; Kanwar, S.S. Organic solvent tolerant lipases and applications. Sci. World J. 2014, 2014, 1-15. [CrossRef] [PubMed]

10. Ribeiro, B.D.; De Castro, A.M.; Coelho, M.A.Z.; Freire, D.M.G. Production and use of lipases in bioenergy: A review from the feedstocks to biodiesel production. Enzyme Res. 2011, 2011, 1-16. [CrossRef]

11. Dhake, K.P.; Thakare, D.D.; Bhanage, B.M. Lipase: A potential biocatalyst for the synthesis of valuable flavour and fragrance ester compounds. Flavour Fragr. J. 2013, 28, 71-83. [CrossRef]

12. De Miranda, A.S. Lipases: Valuable catalysts for dynamic kinetic resolutions. Biotechnol. Adv. 2015, 33, 372-393. [CrossRef]

13. Borrelli, G.M.; Trono, D. Recombinant lipases and phospholipases and their use as biocatalysts for industrial applications. Int. J. Mol. Sci. 2015, 16, 20774-20840. [CrossRef] [PubMed]

14. Zhang, J.; Shi, H.; Wu, D.; Xing, Z.; Zhang, A.; Yang, Y.; Li, Q. Recent developments in lipase-catalyzed synthesis of polymeric materials. Process. Biochem. 2014, 49, 797-806. [CrossRef] 
15. Rodrigues, R.C.; Ortiz, C.; Berenguer-Murcia, Á.; Torres, R.; Fernández-Lafuente, R. Modifying enzyme activity and selectivity by immobilization. Chem. Soc. Rev. 2013, 42, 6290-6307. [CrossRef]

16. Poppe, J.K.; Matte, C.R.; Fernandez-Lafuente, R.; Rodrigues, R.C.; Ayub, M.A.Z. Transesterification of Waste Frying Oil and Soybean Oil by Combi-lipases Under Ultrasound-Assisted Reactions. Appl. Biochem. Biotechnol. 2018, 186, 576-589. [CrossRef]

17. Poppe, J.K.; Matte, C.R.; de Freitas, V.O.; Fernandez-Lafuente, R.; Rodrigues, R.C.; Záchia Ayub, M.A. Enzymatic synthesis of ethyl esters from waste oil using mixtures of lipases in a plug-flow packed-bed continuous reactor. Biotechnol. Prog. 2018, 34, 952-959. [CrossRef] [PubMed]

18. Poppe, J.K.; Matte, C.R.; Do Carmo Ruaro Peralba, M.; Fernandez-Lafuente, R.; Rodrigues, R.C.; Ayub, M.A.Z. Optimization of ethyl ester production from olive and palm oils using mixtures of immobilized lipases. Appl. Catal. A Gen. 2015, 490, 50-56. [CrossRef]

19. Poppe, J.K.; Fernandez-Lafuente, R.; Rodrigues, R.C.; Ayub, M.A.Z. Enzymatic reactors for biodiesel synthesis: Present status and future prospects. Biotechnol. Adv. 2015, 33, 511-525. [CrossRef]

20. Araki, C.A.; Marcucci, S.M.P.; da Silva, L.S.; Maeda, C.H.; Arroyo, P.A.; Zanin, G.M. Effects of a combination of lipases immobilised on desilicated and thiol-modified ZSM-5 for the synthesis of ethyl esters from macauba pulp oil in a solvent-free system. Appl. Catal. A Gen. 2018, 562, 241-249. [CrossRef]

21. Qiao, H.; Zhang, F.; Guan, W.; Zuo, J.; Feng, D. Optimisation of combi-lipases from Aspergillus niger for the synergistic and efficient hydrolysis of soybean oil. Anim. Sci. J. 2017, 88, 772-780. [CrossRef] [PubMed]

22. Amoah, J.; Ho, S.-H.; Hama, S.; Yoshida, A.; Nakanishi, A.; Hasunuma, T.; Ogino, C.; Kondo, A. Lipase cocktail for efficient conversion of oils containing phospholipids to biodiesel. Bioresour. Technol. 2016, 211, 224-230. [CrossRef]

23. Alves, J.S.; Vieira, N.S.; Cunha, A.S.; Silva, A.M.; Záchia Ayub, M.A.; Fernandez-Lafuente, R.; Rodrigues, R.C. Combi-lipase for heterogeneous substrates: A new approach for hydrolysis of soybean oil using mixtures of biocatalysts. RSC Adv. 2014, 4, 6863-6868. [CrossRef]

24. Schoffelen, S.; Van Hest, J.C.M. Multi-enzyme systems: Bringing enzymes together in vitro. Soft Matter 2012, 8, 1736-1746. [CrossRef]

25. Schmid-Dannert, C.; López-Gallego, F. Advances and opportunities for the design of self-sufficient and spatially organized cell-free biocatalytic systems. Curr. Opin. Chem. Biol. 2019, 49, 97-104. [CrossRef]

26. Velasco-Lozano, S.; López-Gallego, F. Wiring step-wise reactions with immobilized multi-enzyme systems. Biocatal. Biotransformation 2018, 36, 184-194. [CrossRef]

27. Sheldon, R.A.; van Pelt, S. Enzyme immobilisation in biocatalysis: Why, what and how. Chem. Soc. Rev. 2013, 42, 6223-6235. [CrossRef] [PubMed]

28. Mateo, C.; Palomo, J.M.; Fernandez-Lorente, G.; Guisan, J.M.; Fernandez-Lafuente, R. Improvement of enzyme activity, stability and selectivity via immobilization techniques. Enzyme Microb. Technol. 2007, 40, 1451-1463. [CrossRef]

29. Iyer, P.V.; Ananthanarayan, L. Enzyme stability and stabilization-Aqueous and non-aqueous environment. Process. Biochem. 2008, 43, 1019-1032. [CrossRef]

30. Barbosa, O.; Ortiz, C.; Berenguer-Murcia, A.; Torres, R.; Rodrigues, R.C.; Fernandez-Lafuente, R. Strategies for the one-step immobilization-purification of enzymes as industrial biocatalysts. Biotechnol. Adv. 2015, 33, 435-456. [CrossRef]

31. Bilal, M.; Cui, J.; Iqbal, H.M.N. Tailoring enzyme microenvironment: State-of-the-art strategy to fulfill the quest for efficient bio-catalysis. Int. J. Biol. Macromol. 2019, 130, 186-196. [CrossRef]

32. Bilal, M.; Asgher, M.; Cheng, H.; Yan, Y.; Iqbal, H.M.N. Multi-point enzyme immobilization, surface chemistry, and novel platforms: A paradigm shift in biocatalyst design. Crit. Rev. Biotechnol. 2019, 39, 202-219. [CrossRef] [PubMed]

33. Bilal, M.; Rasheed, T.; Zhao, Y.; Iqbal, H.M.N.; Cui, J. "Smart" chemistry and its application in peroxidase immobilization using different support materials. Int. J. Biol. Macromol. 2018, 119, 278-290. [CrossRef]

34. Zaak, H.; Kornecki, J.F.; Siar, E.-H.; Fernandez-Lopez, L.; Corberán, V.C.; Sassi, M.; Fernandez-Lafuente, R. Coimmobilization of enzymes in bilayers using pei as a glue to reuse the most stable enzyme: Preventing pei release during inactivated enzyme desorption. Process. Biochem. 2017, 61, 95-101. [CrossRef] 
35. Peirce, S.; Virgen-Ortíz, J.J.; Tacias-Pascacio, V.G.; Rueda, N.; Bartolome-Cabrero, R.; Fernandez-Lopez, L.; Russo, M.E.; Marzocchella, A.; Fernandez-Lafuente, R. Development of simple protocols to solve the problems of enzyme coimmobilization. Application to coimmobilize a lipase and a $\beta$-galactosidase. RSC Adv. 2016, 6, 61707-61715. [CrossRef]

36. Garcia-Galan, C.; Berenguer-Murcia, Á.; Fernandez-Lafuente, R.; Rodrigues, R.C. Potential of different enzyme immobilization strategies to improve enzyme performance. Adv. Synth. Catal. 2011, 353, 2885-2904. [CrossRef]

37. Rodrigues, R.C.; Virgen-Ortíz, J.J.; dos Santos, J.C.S.; Berenguer-Murcia, Á.; Alcantara, A.R.; Barbosa, O.; Ortiz, C.; Fernandez-Lafuente, R. Immobilization of lipases on hydrophobic supports: immobilization mechanism, advantages, problems, and solutions. Biotechnol. Adv. 2019. In press. [CrossRef]

38. Manoel, E.A.; dos Santos, J.C.S.; Freire, D.M.G.; Rueda, N.; Fernandez-Lafuente, R. Immobilization of lipases on hydrophobic supports involves the open form of the enzyme. Enzyme Microb. Technol. 2015, 71, 53-57. [CrossRef]

39. Bastida, A.; Sabuquillo, P.; Armisen, P.; Fernández-Lafuente, R.; Huguet, J.; Guisán, J.M. A single step purification, immobilization, and hyperactivation of lipases via interfacial adsorption on strongly hydrophobic supports. Biotechnol. Bioeng. 1998, 58, 486-493. [CrossRef]

40. Fernandez-Lafuente, R.; Armisén, P.; Sabuquillo, P.; Fernández-Lorente, G.; Guisán, J.M. Immobilization of lipases by selective adsorption on hydrophobic supports. Chem. Phys. Lipids 1998, 93, 185-197. [CrossRef]

41. Palomo, J.M.; Muoz, G.; Fernández-Lorente, G.; Mateo, C.; Fernández-Lafuente, R.; Guisán, J.M. Interfacial adsorption of lipases on very hydrophobic support (octadecyl-Sepabeads): Immobilization, hyperactivation and stabilization of the open form of lipases. J. Mol. Catal. B Enzym. 2002, 19-20, 279-286. [CrossRef]

42. Dos Santos, J.C.S.; Rueda, N.; Torres, R.; Barbosa, O.; Gonçalves, L.R.B.; Fernandez-Lafuente, R. Evaluation of divinylsulfone activated agarose to immobilize lipases and to tune their catalytic properties. Process. Biochem. 2015, 50, 918-927. [CrossRef]

43. Dos Santos, J.C.S.; Rueda, N.; Gonçalves, L.R.B.; Fernandez-Lafuente, R. Tuning the catalytic properties of lipases immobilized on divinylsulfone activated agarose by altering its nanoenvironment. Enzyme Microb. Technol. 2015, 77, 1-7. [CrossRef]

44. Santos, J.C.S.; Rueda, N.; Sanchez, A.; Villalonga, R.; Gonçalves, L.R.B.; Fernandez-Lafuente, R. Versatility of divinylsulfone supports permits the tuning of CALB properties during its immobilization. Process. Biochem. 2015, 5, 35801-35810. [CrossRef]

45. Rueda, N.; dos Santos, J.C.S.; Torres, R.; Ortiz, C.; Barbosa, O.; Fernandez-Lafuente, R. Improved performance of lipases immobilized on heterofunctional octyl-glyoxyl agarose beads. RSC Adv. 2015, 5, 11212-11222. [CrossRef]

46. Suescun, A.; Rueda, N.; dos Santos, J.C.S.; Castillo, J.J.; Ortiz, C.; Torres, R.; Barbosa, O.; Fernandez-Lafuente, R. Immobilization of lipases on glyoxyl-octyl supports: Improved stability and reactivation strategies. Process. Biochem. 2015, 50, 1211-1217. [CrossRef]

47. Mateo, C.; Abian, O.; Bernedo, M.; Cuenca, E.; Fuentes, M.; Fernandez-Lorente, G.; Palomo, J.M.; Grazu, V.; Pessela, B.C.C.; Giacomini, C.; et al. Some special features of glyoxyl supports to immobilize proteins. Enzyme Microb. Technol. 2005, 37, 456-462. [CrossRef]

48. Arana-Peña, S.; Lokha, Y.; Fernández-Lafuente, R. Immobilization on octyl-agarose beads and some catalytic features of commercial preparations of lipase a from Candida antarctica (Novocor ADL): Comparison with immobilized lipase B from Candida antarctica. Biotechnol. Prog. 2019, 35, e2735. [CrossRef]

49. Virgen-Ortíz, J.J.; dos Santos, J.C.S.; Ortiz, C.; Berenguer-Murcia, Á.; Barbosa, O.; Rodrigues, R.C.; Fernandez-Lafuente, R. Lecitase ultra: A phospholipase with great potential in biocatalysis. Mol. Catal. 2019, 473, 110405. [CrossRef]

50. Rodrigues, R.C.; Fernandez-Lafuente, R. Lipase from Rhizomucor miehei as a biocatalyst in fats and oils modification. J. Mol. Catal. B Enzym. 2010, 66, 15-32. [CrossRef]

51. Rodrigues, R.C.; Fernandez-Lafuente, R. Lipase from Rhizomucor miehei as an industrial biocatalyst in chemical process. J. Mol. Catal. B Enzym. 2010, 64, 1-22. [CrossRef]

52. Arana-Peña, S.; Mendez-Sanchez, C.; Rios, N.S.; Ortiz, C.; Gonçalves, L.R.B.; Fernandez-Lafuente, R. New applications of glyoxyl-octyl agarose in lipases co-immobilization: Strategies to reuse the most stable lipase. Int. J. Biol. Macromol. 2019, 131, 989-997. [CrossRef] 
53. Rios, N.S.; Pinheiro, B.B.; Pinheiro, M.P.; Bezerra, R.M.; dos Santos, J.C.S.; Gonçalves, L.R.B. Biotechnological potential of lipases from Pseudomonas: Sources, properties and applications. Process. Biochem. 2018, 75, 99-120. [CrossRef]

54. Cerminati, S.; Paoletti, L.; Aguirre, A.; Peirú, S.; Menzella, H.G.; Castelli, M.E. Industrial uses of phospholipases: current state and future applications. Appl. Microbiol. Biotechnol. 2019, 103, 2571-2582. [CrossRef]

55. Rios, N.S.; Sanchez, C.M.-; Arana-Peña, S.; Rueda, N.; Lokha, Y.; Ortiz, C.; Gonçalves, L.R.B.; Fernandez-Lafuente, R. Immobilization of lipase from Pseudomonas fluorescens on glyoxyl-agarose beads: improved stability and reusability. Submitt. Biochim. Biophys. Acta Proteins Proteomics 2019. Under revisión.

56. Rueda, N.; dos Santos, J.C.S.; Ortiz, C.; Barbosa, O.; Fernandez-Lafuente, R.; Torres, R. Chemical amination of lipases improves their immobilization on octyl-glyoxyl agarose beads. Catal. Today 2016, 259, 107-118. [CrossRef]

57. Bradford, M.M. A rapid and sensitive method for the quantitation of microgram quantities of protein utilizing the principle of protein-dye binding. Anal. Biochem. 1976, 72, 248-254. [CrossRef]

58. Laemmli, U.K. Cleavage of Structural Proteins during the Assembly of the Head of Bacteriophage T4. Nature 1970, 227, 680-685. [CrossRef]

59. Virgen-Ortíz, J.J.; Tacias-Pascacio, V.G.; Hirata, D.B.; Torrestiana-Sanchez, B.; Rosales-Quintero, A.; Fernandez-Lafuente, R. Relevance of substrates and products on the desorption of lipases physically adsorbed on hydrophobic supports. Enzyme Microb. Technol. 2017, 96, 30-35. [CrossRef] [PubMed]

(C) 2019 by the authors. Licensee MDPI, Basel, Switzerland. This article is an open access article distributed under the terms and conditions of the Creative Commons Attribution (CC BY) license (http://creativecommons.org/licenses/by/4.0/). 